Costly bank bailouts, such as those during the 2007-2009 global financial crisis, are commonly attributed to policy "capture" by financial and corporate interests (Johnson and Kwak, 2010). These perceptions have been associated with rising political contestation, polarization and instability in mature democracies, with disruptive consequences for longestablished foreign and domestic policy norms (Tooze, 2018). We argue that crisis policy responses and their political aftermaths have become increasingly consequential, but should be understood in a panoramic context that takes account of a new form of mass politics associated with increasingly financialized middle class wealth. It reveals that the interaction between democratic politics and financialized wealth has destabilized both increasingly integrated financial systems and the socio-political underpinnings of neoliberal policy norms at the domestic and global levels.

Our argument builds on and integrates different literatures: on financialization, which has devoted limited attention to post-crisis politics (Finlayson, 2009; Langley, 2009; van der Zwan, 2014; Watson, 2007); on comparative and international political economy research showing how rising household wealth and wealth inequality generate new political cleavages and shape actor behaviour (Ansell, 2014; Curtis et al., 2014; Pagliari et al., 2018; Schwartz and Seabrooke, 2009); on comparative post-crisis electoral politics (Ansell, 2017a; Bartels and Bermeo, 2014); and on the roles of evolutionary change and long cycles in the global political economy (Blyth and Matthijs, 2017; Fioretos, 2017).

Specifically, we show how the financialization of mass household wealth has complicated and sharply raised the bar for government performance during major banking crises, with destabilizing political consequences. In democracies, many voters have become far more attentive to potential and actual wealth losses, and the perceived fairness of their distribution. Contrary to neoliberal policy norms and narratives of personal responsibility offered by politicians promoting financialization, most voters now expect governments to 
protect their wealth during crises. Modern governments often accordingly intervene extensively to prevent catastrophic wealth destruction, offering bailouts that go far beyond the "Bagehot rule" of lending to normally solvent banks in return for good collateral (Bagehot, 1962; Rosas, 2006). Yet even modest wealth losses and perceived inequities of treatment can still be fatal for political incumbents and have powerful consequences for domestic and international politics.

Elsewhere, using a large cross-national dataset extending from the early nineteenth to the early twenty first centuries, we show that rising household wealth in democracies is strongly associated with more extensive bailouts and rising political instability (Chwieroth and Walter 2019). It is also essential to investigate causal mechanisms in particular contexts (Lieberman, 2005; Munck and Snyder, 2007). "Nested analysis" can provide one means of doing this, but it is methodologically challenging (Rohlfing, 2008). We therefore provide additional justifications for our case selection.

We compare long run developments in two major democracies - Britain and the United States - that are theoretically "typical" and "crucial" cases. Over the past two centuries, both exhibit large variation in our independent variables, democratization and the financialization of wealth and are at their leading edge (Lieberman 2005: 442-444). Until recently, they have also been prominently associated with global economic policy leadership and neoliberal policy norms. Within- and comparative case analysis allows us to gain deeper insight into the causal mechanisms shaping the policy and political outcomes of interest, enabling an assessment of our argument alongside alternative theories, for which both countries are often seen as crucial cases. We explore how the interaction between long run processes of democratization and the (more recent) financialization of mass wealth have reshaped policy interventions and the political aftermaths of systemic banking crises. We distinguish between an earlier era of "elite wealth dominance" and a more recent era of 
"financialized mass wealth," corresponding to the "old" and "new" politics of banking crises. The high concentration of wealth among elites in pre-1914 Britain and America was associated both with limited crisis interventions and surprisingly tranquil political aftermaths. By contrast, the 2007-9 crises in both countries epitomise the policy and political dilemmas facing elected governments in a new era of mass financialized wealth. We also briefly discuss how the iconic US case in the Great Depression indicates the transitional nature of this era.

\section{Theory and method}

We claim that evolutionary processes of democratization and the financialization of mass wealth have interacted to transform policy interventions and the political aftermaths of major banking crises in ways that have received insufficient attention (Bartels, 2014; CrespoTenorio et al., 2014). In modern crises, since no longer only the wealth of a narrow group of elites is at risk, governments face much greater pressure to protect wealth from a wider political coalition comprising the middle class and wealthy elites. Yet these processes also render such interventions fraught with political risk.

We follow others in defining the middle class as "those [households] 'comfortably' clear of being at-risk-of-poverty" but lacking sufficient wealth not to need to work (Atkinson and Brandolini, 2013: 79). We first briefly review evidence that middle class wealth grew to become substantial and financialized.

Real per adult wealth has grown exponentially since the 1950s (Figure 1). Despite recent increases in wealth inequality in some countries (notably the United States), this trend applies generally to middle class households, with substantial variation within this category (Kuhn et al., 2018; Wolff, 2017a, 2017b; World Wealth \& Income Database, 2017). Furthermore, middle class wealth has become increasingly financialized, meaning that its value reflects "the increasing role of financial motives, financial markets, financial actors and 
financial institutions in the operation of the domestic and international economies" (Epstein, 2005b: 3). Housing equity now dominates middle class wealth portfolios, whereas a century ago only a minority of households were owner-occupiers (Domanski et al., 2016: 62; United Nations Human Settlements Program, 2006). This was facilitated by a boom in post-war mortgage lending, linking housing equity values to the availability and cost of credit (Jordà et al., 2016). Pension assets, now the second largest component of middle class wealth portfolios, have shown a similar post-war trajectory and become increasingly financialized due to pension privatization and a shift towards defined contribution (DC) schemes (Brooks, 2005). 
Figure 1: Real net personal wealth per adult, selected countries 1850-2015, constant 2016 US dollars and PPP exchange rates

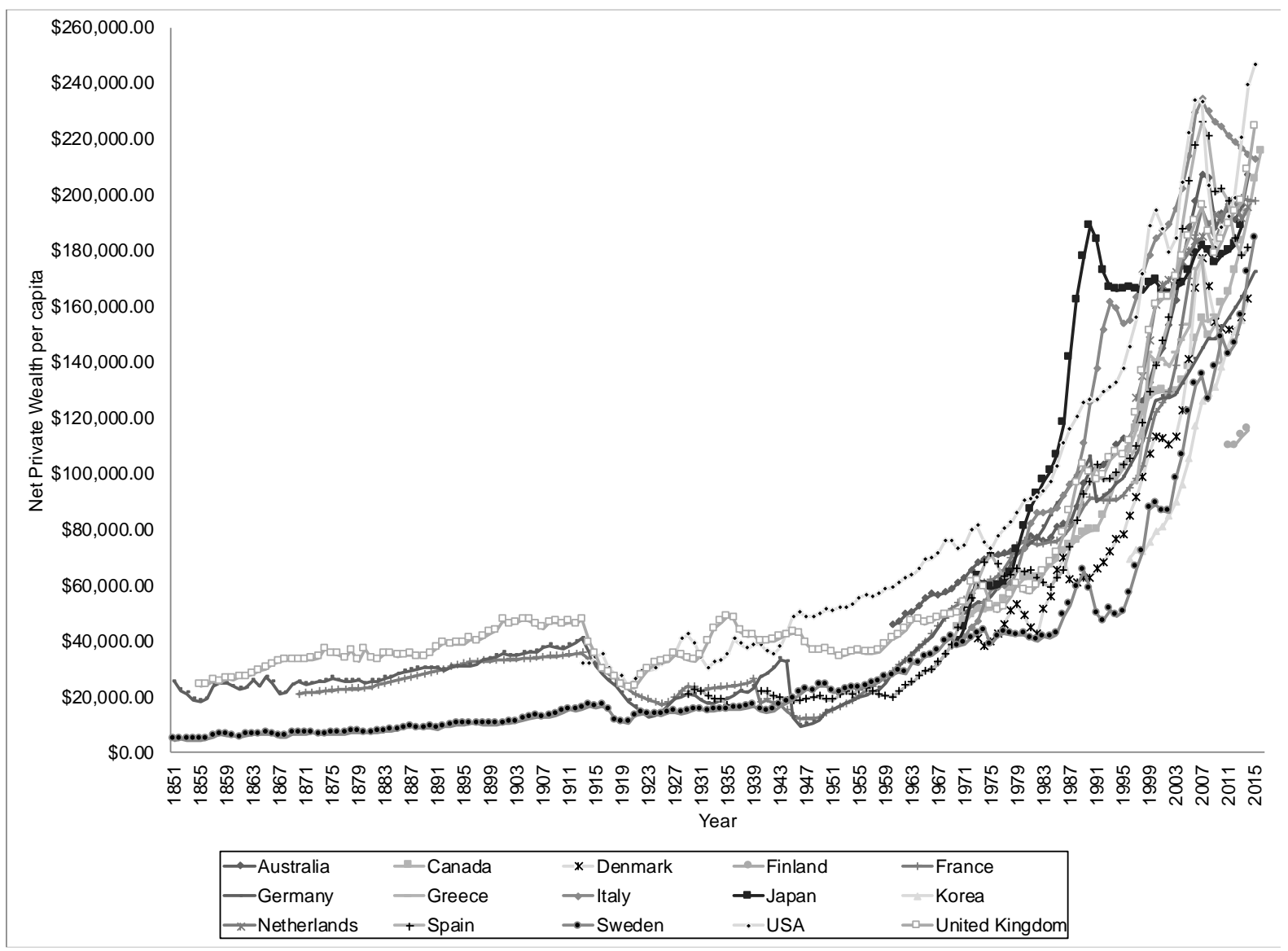

Source: (World Wealth \& Income Database, 2017).

These core characteristics of mass wealth - its increased size, changing composition and rising exposure to financial markets - mean that many in the middle class have become more anxious about potential losses (Board of Governors of the Federal Reserve System, 2017: 10-14; Watson, 2007). This has generated the emergence of "great expectations" among this crucial group of voters regarding government responsibility for wealth protection when it is threatened by financial instability (Chwieroth and Walter 2019). Democratization and suffrage expansions over the nineteenth and early twentieth centuries have increased this group's ability to place electoral pressure on governments to meet these expectations. 
Mass financialized wealth is historically recent. To illustrate in the British case, in the early nineteenth century, most wealth was property and business capital held by wealthy elites - a sizeable middle "wealth" class did not exist (Lindert, 1986; Offer, 1991; Piketty and Zucman, 2015). In 1873, less than a sixth of all households owned their own home; only 23 percent did in 1918 (Lindert, 1986: 1142). Middle class home ownership grew rapidly after 1945, peaking at 69 percent in 2001; the rapid expansion of mortgage lending made this possible (Jordà et al., 2016; Office for National Statistics, 2013). By 2008, about 55 percent of domestic wealth consisted of housing assets (Piketty and Zucman, 2015, fig. 15.1). Similarly, before 1945, household pensions comprised less than 0.03 percent of all financial assets, but they grew to roughly eight percent by 1966 and about 40 percent since 1987, with a strong trend towards market-exposed DC schemes from the 1980s (Office for National Statistics, 2014; Roe, 1971). The proportion of households with direct ownership of shares also grew from less than nine percent in 1983 to 22 percent in 1998 (Guiso et al., 2003), with such exposure increasing from the middle quintiles of the distribution. These characteristics distinguish the middle class from the very wealthy, for whom financial portfolio assets now dominate, housing and pension assets are relatively unimportant, and leverage far lower. These trends are largely replicated in the United States and other advanced democracies (Hoffman et al., 2009: 79-82; Wolff, 2017a, 2017b).

Why should governments that respond to financial instability with policy interventions now be more likely to suffer politically? Fundamentally, this is because great expectations set a new, higher bar for government performance during crises that most incumbents find difficult to meet. First, voters with an enhanced stake in financial stability will likely interpret the onset of banking crises as an "incompetency signal." Second, even well-managed crises are typically associated with large income and wealth losses (Reinhart and Rogoff, 2009). Most voters hold government responsible because a personal 
responsibility narrative is unattractive given growing dependence on "asset-based welfare" (Fligstein and Goldstein, 2015; Langley, 2009; Pagliari et al., 2018). People are also lossaverse and less likely to attribute losses to personal choices than gains (Kahneman and Tversky, 1984). Third, modern voters' great expectations are often unrealistic, inconsistent and riddled with conflict. They want governments to protect their wealth but bridle at the large costs and inequity of bailing out institutions and bankers perceived as privileged and irresponsible. That is, many expect "ideal" interventions governments cannot achieve, which decisively and equitably alleviate financial distress for "ordinary" people at least cost to taxpayers (Financial Services Authority (UK), 2012; van der Cruijsen et al., 2013). Notably, governments cannot easily avoid supporting the large financial institutions at the centre of modern financial networks (Haldane and May, 2011). Institutional constraints mean that governments also respond slowly rather than decisively in crises (MacIntyre, 2003; Oatley, 2004), exacerbating market contagion and wealth losses and raising bailout costs. All this allows media critics and political rivals to portray crisis interventions as excessively costly, delayed, misjudged, inadequate and unfair.

Our argument departs from the "clarity of responsibility" hypothesis that voters will be more forgiving if low political and institutional unity makes it difficult to assign responsibility to individual policymakers (Powell and Whitten, 1993). Systemic banking crises differ from standard recessions in their comparative rarity and by exposing ordinary households to sudden, large wealth losses, placing a premium on a government's ability to act quickly and efficiently. Most voters cannot judge whether delays or policy failures are the result of institutional constraints, deliberate choice, or incompetence. Banking crises can also generate policy gridlock by exacerbating creditor-debtor conflict, raising economic inequality and ideological polarization, and favouring selective interventions that appear to benefit special interests (Funke et al., 2016; McCarty et al., 2015; Mian et al., 2014). For these 
reasons, voters will tend to judge government performance in the context of intra-crisis policy constraints negatively. Modern governments therefore face acute challenges in crises: they know that the political costs of not intervening are almost certainly greater than intervening, but the electoral rewards from intervention are tenuous.

Our theory produces two main empirical expectations. First, democratization and the financialization of mass wealth should together have led to more extensive bailouts during systemic crises. Second, the propensity of modern voters to punish incumbent governments after crises should also have increased, especially when policy responses are perceived as delayed and unfairly redistributive.

To investigate them, we undertake within- and across-case comparative analysis of the aftermaths of major banking crises in two important countries, Britain and the United States, before 1914 and over 2007-10, focusing on the large over-time variation in democracy and the financialization of wealth. We select these cases for two further reasons: both countries have become "exemplar financialized economies" (French et al., 2011: 805) and thus "crucial cases" for assessing its consequences (Gerring and Cojocaru, 2015); and both are crucial cases for alternative theories.

One such theory is that non-democratic regimes are more likely than democracies to undertake bailouts during banking crises due to entrenched elite rent-seeking (Rosas, 2009). Thus, democratization should promote less extensive bailouts, though partisan politics may produce different responses (Garrett 1998). Others argue that the rise of neoliberalism since the 1970s has made governments less willing to intervene (Blyth, 2002), or that globalization has had a constraining effect (Andrews, 1994). Globalization is also said to make it less likely that voters will assign blame to incumbents (Hellwig and Samuels, 2007). For these theories, Britain and the United States are plausible crucial cases for claims concerning neoliberalism and globalization and differed in their partisan orientation over 2007-8. 
Another school makes the opposite claim that bailouts should increase as financial actors "capture" policymaking, either via their extensive resources (Hacker and Pierson, 2010; Johnson and Kwak, 2010) or the structural power deriving from their centrality to mature economies (Bell and Hindmoor, 2015; Culpepper and Reinke, 2014). These authors see recent experience in Britain and the United States as paradigmatic but identify different mechanisms to ours.

To date, these competing claims have been assessed using historically narrow and recent time-windows. We extend the time horizon over nearly two centuries to examine the long UK and US experience with banking crises to better assess our theory against these alternatives. Our analysis here and elsewhere takes account of varying crisis frequency and severity, as well as financial openness (see online appendix and Chwieroth and Walter, 2019).

\section{Pre-1914 crises}

We first consider the political consequences of the financial crisis in England in 18256, the deepest before 2007-9 (Turner, 2014: 57-61). Even in 1825, policymakers possessed sufficient knowledge and policy tools to implement lender of last resort (LOLR) policies and bailouts. Both sets of policies had been pursued in earlier crises, including in 1793 (Bagehot, 1962, chap. 7; Grossman, 2010: 99-101; Turner, 2014: 140-147). With its highly distressed financial sector and very limited democracy, we might expect elite rent-seeking to have induced a bailout in 1825 , but we show this was not the case. Nor, despite the severe economic downturn and wealth destruction that followed, did the government's policy stance play much role in contested 1826 elections.

We then discuss the deep crisis of 1907 in the United States (Figure 2), where the majority of adult males were enfranchised - in sharp contrast to 1820s Britain. The United 
States then lacked a central bank, focusing political pressure for crisis intervention on the Treasury. Yet the government chose to rely heavily on private sector actions that were insufficient to prevent an exceptionally deep downturn, again with few electoral consequences.

Figure 2: Real GDP growth before and after five systemic banking crises in the United Kingdom and the United States, with next election years

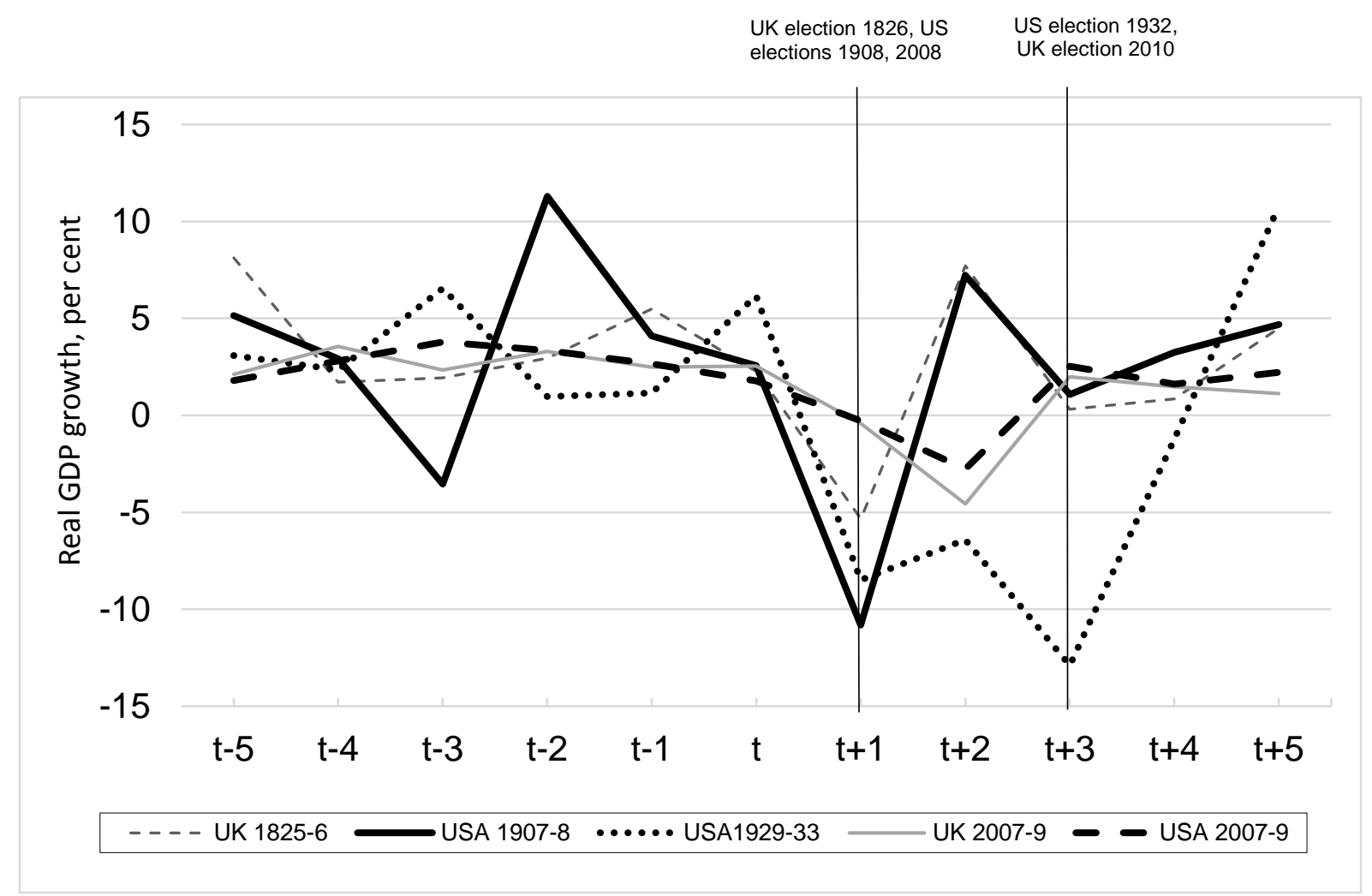

Source: (Johnson and Williamson, 2017; Thomas and Dimsdale, 2017). $\mathrm{t}=$ the first year of each crisis (Reinhart, 2010). Vertical lines indicate the next election year. For the UK, GDP growth estimates are for geographically consistent post-1922 political boundaries. 


\subsection{The 1825-6 English crisis}

A panic developed after the bursting of a speculative bubble in early 1825 that first affected English country banks but by December had spread to London (Kindleberger and Aliber, 2011: 88; Thomas, 1934: 61-64; Turner, 2014: 67). Nearly 10 percent (73 of 770) of country banks failed during this crisis and informed contemporaries believed the country came close to complete financial collapse (Kindleberger and Aliber, 2011: 111; Thomas, 1934: 55-56). After a hesitant and much-criticized initial response, the Bank of England provided liquidity assistance to banks on commercial terms that stemmed the financial crisis in late December. A deep recession and a "massive" wave of bankruptcies followed in early 1826 (Gayer et al., 1975: 205).

The main constituency favouring extensive intervention was the financial and merchant community in London and in the country. They did not lack political connections. Four MPs' banks failed in the crisis (Fisher, 2009: 270). The Bank and other bankers pressured the government to suspend gold convertibility, as it had done from 1797 to 1821 (Thomas, 1934: 56). Parliamentary representatives associated with the merchant class called for the emergency issuance of Exchequer bills to distressed merchants in exchange for goods collateral.

Lord Liverpool's Tory government rejected these demands (Brock, 1967: 210). It is unlikely this was due to a lack of physical (note issuance) or fiscal capacity: the government ran large net and primary fiscal surpluses during the 1820 s and the ratio of public debt to GDP was falling (Thomas and Dimsdale, 2017). However, Liverpool convened a meeting with the Bank's governor and encouraged him to print money and lend extensively against sound collateral (Brock, 1967: 205). Although privately owned and constrained by its public responsibility to maintain sterling's gold convertibility, the Bank's governors agreed reluctantly, keenly aware that its performance would shape political decisions about its next 
charter renewal in 1833 (Kindleberger and Aliber, 2011: 217). It lent extensively to other firms by discounting bills and issuing new notes on collateral (Brock, 1967: 206).

This LOLR lending was largely consistent with the market-conforming approach advocated by Thornton, including collateralized lending and screening of borrowers (Bagehot, 1962: 25). It was not an indiscriminate bailout: dozens of insolvent financial institutions were allowed to fail. The government did indicate a willingness to reimburse Bank losses on advances it made on the limited quantity of Exchequer Bills outstanding, but it refused direct government relief to distressed firms.

Despite Tory concerns with maintaining social order (Gambles 1999), there is little indication that Liverpool's government, approaching its seven-year maximum duration, was seriously destabilized by this stance or by the deep recession that followed. The main issue in the 1826 election was not the government's crisis policy stance but Catholic emancipation. There was no substantial swing against the Tories and the government was comfortably returned (Fisher, 2009: 329-330).

The available evidence suggests this was not due to a shortage of contested elections. Of 28 individual bank failures we have identified from one key historical source, 11 occurred in constituencies with elections in 1826 (Fisher, 2009; Orbell and Turton, 2001). In these constituencies, in almost all cases where sitting Tories ran, they enjoyed an increase in their vote share. ${ }^{1}$

The limited electoral impact of the government's policy stance was probably linked to the salience of the emancipation question, but also to the great importance of land holdings in the wealth of the narrow electorate. Between 1820 and the Reform Act of 1832, the electoral franchise was property-based and included about three percent of the population (House of

\footnotetext{
${ }^{1}$ Author analysis of election data in Fisher (2009).
} 
Commons Library, United Kingdom, 2013: 3-4). The landed elite dominated both houses of parliament. Estimates suggest that land values and rental income were relatively stable following the crisis (Gayer et al., 1975: 929; Jaevicius et al., 2015: 18). Land-owning voters also likely minimized their vulnerability to country bank failures by maintaining their primary accounts with London bankers, including the Bank of England (Pressnell, 1956: 246-247). In short, the evidence suggests that Liverpool's government faced a low level of political risk in choosing limited intervention. The pro-bailout coalition lacked political influence because of the high concentration of wealth and substantial intra-elite opposition to bailouts.

\subsection{The 1907-8 U.S. crisis}

Compared with 1820s Britain, the United States by 1907 exhibited much higher levels of democracy, financial development, and a more substantial middle class (Piketty and Zucman, 2014). Following a build-up of speculative pressure and banking sector fragility, a failed scheme to corner the copper market unleashed a sudden panic in New York in midOctober 1907 (Bruner and Carr, 2007: 7-55). Smaller banks connected with the copper speculation and the Knickerbocker Trust Company applied unsuccessfully for financial assistance to the New York Clearing House (NYCH), a private consortium dominated by the city's major banks. Panic spread, with about 70 banks and trusts collapsing over the final months of 1907 and some states declaring bank holidays (Conant, 1915: 714-718;

Kindleberger and Aliber, 2011: 212; Moen and Tallman, 1992). Total commercial failures in 1908 increased by nearly 40 percent over the average levels of 1905-7, especially in Middle, Southern and Western states (U.S. Department of Commerce and Labor, 1910: 547-549). The economy shrank by nearly 11 percent in 1908 and the unemployment rate reached over 16 percent (Douglas and Director, 1931: 28). 
Total U.S. deposits fell by about six percent from September to December 1907 (Jaremski and Rousseau, 2018). Depositor losses were concentrated in state banks rather than in better capitalized national banks (Gorton, 1988). Real stock prices fell about 40 percent from their peak in September 1906 in the lead up to the October 1907 crisis, but largely recovered by the November 1908 elections. Real average house prices were less resilient, falling about 15 percent from their 1907 peak to their 1910 trough (Shiller, n.d.). However, such losses only affected a minority of wealthier households.

Following Knickerbocker's collapse, the NYCH moved, under the leadership of John Pierpont Morgan, to stem the panic by lending to the Trust Company of America and brokers at the New York Stock Exchange (Bruner and Carr, 2007: 83-102). At Morgan's request, the Treasury deposited more government cash in approved banks and widened the acceptable range of instruments national banks could use to back note issuance (Conant, 1915: 714; McCulley, 1992: 100-147; Taus, 1943: 123-125). However, by early November the Treasury was running out of cash and failed to do much more (Bruner and Carr, 2007: 22, 34, 86-87, 136). The NYCH responded by issuing over $\$ 100$ million of loan certificates and suspending cash payments (McCulley, 1992: 146-147). The panic eventually subsided in early November with the provision of further substantial private sector assistance to major New York trusts, the news that nearly $\$ 100$ million in gold had arrived from Europe, and the announcement that US Steel would acquire the financially distressed Tennessee Coal and Iron (TCI) company (Bruner and Carr, 2007: 108, 124-139).

The government saw limited demand from the great majority of voters for bailouts. Most US households then held little wealth and their exposure to financial markets was low by late twentieth century standards (Piketty and Zucman, 2015; Short, 2002). Reflecting this, there was no strong clamour from the opposition Democrats or their constituents for more extensive government intervention, with the exception of demands by poor farmers for 
deposit insurance championed by William Jennings Bryan. While these interests would later under Woodrow Wilson shape the creation of the Federal Reserve and a new farm credit system, the government, along with financial interests, most major newspapers outside the West and orthodox economists, rejected this demand (McCulley, 1992: 155-158; Sanders, 1999: 236-261).

The powerful negative economic impact of the crisis would very likely have harmed the incumbent Republican Party in a more recent presidential contest. Yet its candidate, William Howard Taft, easily beat his Democratic opponent, Bryan, by 51.1 percent of the popular vote to 43 percent in the election of November 1908. The weak political impact of the banking crisis is also indicated by the fact that states with more bank failures were not significantly more likely to inflict greater punishment on the Republican presidential candidate in November 1908 (Figure 3) or on the party’s congressional candidates. ${ }^{2}$

\footnotetext{
${ }^{2}$ The results are unchanged when we consider national bank failures. The bivariate relationship for the congressional seat outcomes is insignificant including $(.0047, \mathrm{p}=.795)$ and excluding $(-.005, \mathrm{p}=.709)$ potential outliers.
} 
Figure 3: Bank failures by U.S. state, 1907-8, and percent change in Republican presidential candidate vote share, $1904-8$

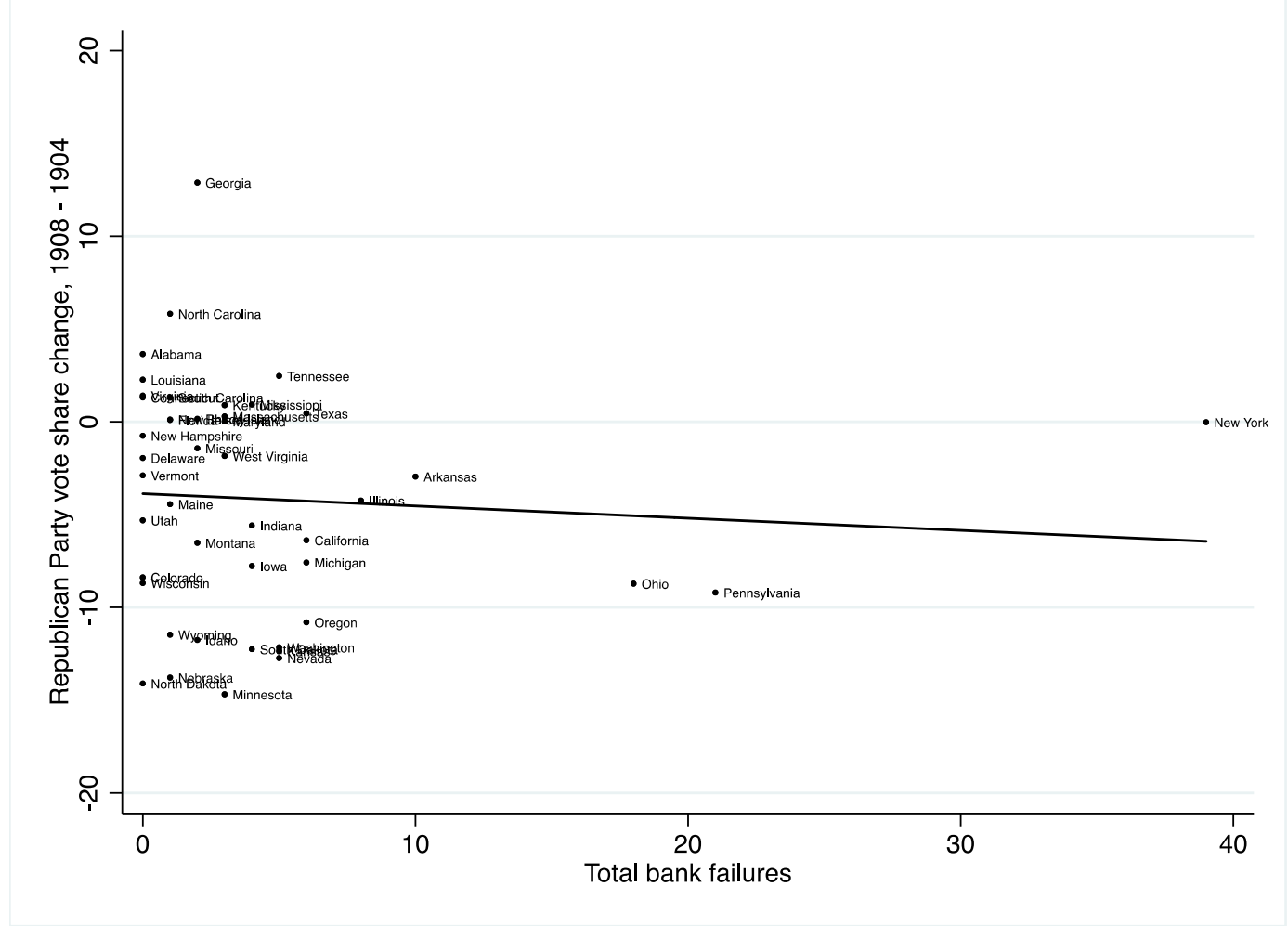

Source: (Comptroller of the Currency (U.S.), 1909; Moore, 1985). The bivariate relationship is insignificant including $(-.072, \mathrm{p}=.6364)$ and excluding $(-.2450, \mathrm{p}=.1132)$ potential outliers.

Taken together, these results support our claim that the low level of mass wealth lowered the political risks of a non-interventionist policy stance.

3 The $2007-9$ crises in the United Kingdom and the United States

Government interventions were far more extensive over 2007-9 in both countries. In addition to exceptionally large central bank liquidity provision, governments provided unprecedented public guarantees to previously uninsured financial system liabilities, purchased private institutions' distressed assets, and injected capital into major financial 
institutions (Laeven and Valencia, 2013). These outcomes are inconsistent with broad claims that greater democracy, globalization and neoliberal ideology are powerful constraints on government bailouts. We show that the financialization of mass wealth in both democracies provides a more compelling explanation of these policy responses and of the much greater electoral punishment that followed.

\subsection{British policy responses and the political aftermath}

One reason why the Labour government gained little political advantage from its crisis interventions was that the opposition Conservative and Liberal Democratic parties quickly supported public intervention and distanced themselves from the banks, focusing attention on internal conflict among "New" and "Old" Labour Party factions (Darling, 2011: $54,68,174)$. They framed specific aspects of the package as overly costly, distributionally unfair but, crucially, as the economic costs of the crisis accumulated, also ineffective. These tactics demonstrate that all major parties were now responding to voters' entrenched great expectations. As our theory predicts, the outbreak of the crisis from August 2007 sent voters a strong negative signal regarding Prime Minister Gordon Brown’s signature economic policy competence (BBC News, 2007; Croft, 2007). Public support for the Labour government collapsed after August 2007, falling from about 40 percent to about 25 percent by June 2008, by which time the Conservative opposition had a commanding lead. Brown and Chancellor Alastair Darling were keenly aware of these reputational consequences and their reluctance to discard the defining ideological attributes of "New Labour" led them to delay nationalizing Northern Rock for months until there was no alternative. Brown also sought to deflect responsibility by asserting that the crisis was "global" in nature, a tactic doomed by his earlier embrace of "light touch" financial regulation (Coates, 2009: 424-425; Foley, 2009). 
Also consistent with our argument, voters responded more positively when the government acted with greater speed and purpose during the peak of the crisis in late 2008 (Quaglia, 2009). Support for the government recovered somewhat in the second half of 2008, including during the peak of the crisis in September-October 2008 and the large interventions that followed this. However, the aggregate size of the banking sector support package continued to escalate in the following months, reaching a spectacular 80 percent of GDP by 2009 (International Monetary Fund, 2010: 17). This deepened the public perception that bankers were being rescued while large costs would be borne by taxpayers and public sector beneficiaries - despite government denials. This growing perception of distributional inequity and the onset of income and wealth destruction fatally eroded voter support for Labour from early $2009 .^{3}$

For many voters outside London, this was made worse by the fact that the perceived recipients of this largesse were located there, notably highly paid City financiers and the highly distrusted banks (British Social Attitudes, n.d.). Pre-crisis gains in housing wealth were also disproportionately concentrated in London and surrounding counties, and sustained thereafter (Haldane, 2016: 19). The government's counterfactual argument that everyone would have been far worse off had it not intervened thus gained little political traction (Financial Times, 2009; Haldane, 2018: 4-5). As the economy deteriorated over 2009, public support for the financial sector interventions fell substantially. The middle class was hit hardest: excepting the bottom two quartiles, most households saw their real incomes and wealth fall or stagnate in the period before the 2010 election (Office for National Statistics, 2017). This was particularly true for younger households, who were more leveraged and more likely to hold DC pensions, and for households outside London and the Southeast living

\footnotetext{
${ }^{3}$ For additional detail on the evolution of British public opinion see the online appendix.
} 
in regions suffering from long term decline (Corlett and Judge, 2017: 30; Rodríguez-Pose, 2018). Average house prices fell by about 15 percent in real terms from 2008 to 2010 (Knoll et al., 2017: 344), yet continued to rise in wealthier parts of London and the Southeast, exacerbating perceptions of unfairness. Average real per capita wealth fell by nine percent from 2007 to 2009 while the wealth share of the top one percent of households increased; many voters also perceived inequality as rising (Atkinson et al., 2017; PewResearchCenter, 2013: 21-22). The government's political room for fiscal redistribution was constrained by ideology and its electoral strategy, which had depended on gaining the support of relatively prosperous centrist voters (Hopkin and Viarengo, 2012: 119). Rising public resentment about the distributional effects of the interventions limited the credit the government could claim from "saving the economy" (Woll, 2014: 106).

Labour was decisively defeated in the May election, gaining 29 percent of the vote compared to 36 percent for the Conservatives and 23 percent for the Liberal Democrats. The swing against the government was -6.2 percent compared to 2005 . This was the second worst electoral result for the Labour Party since the war, only marginally better than the disastrous 1983 election.

To our knowledge, there are no opinion surveys that directly relate voter attitudes to government policy responses over 2007-9 with household wealth and leverage attributes. Surveys by the financial regulator since 2003 do consistently show that only about $30 \%$ of respondents hold the view that, in principle, the authorities will allow any financial firm to fail (Financial Services Authority (UK), 2012: 34). The remainder believe that either some or all will be bailed out (41\% over the pre-crisis period $2003-7)$, or don't know (26\% on average over the same period) (Financial Services Authority (UK), 2009: 26). While these results are not differentiated by respondent wealth attributes, there are strong indications that Labour's electoral losses were related to such attributes. In May 2010, the government experienced 
disproportionately large losses in constituencies in which house prices had fallen most - that is, precisely where the middle class was most exposed to wealth losses (Figure 4).

Figure 4: House price index percentage change (June 2007 to May 2010) and Labour Party vote percentage change (2010 vs. 2005), all parliamentary constituencies.

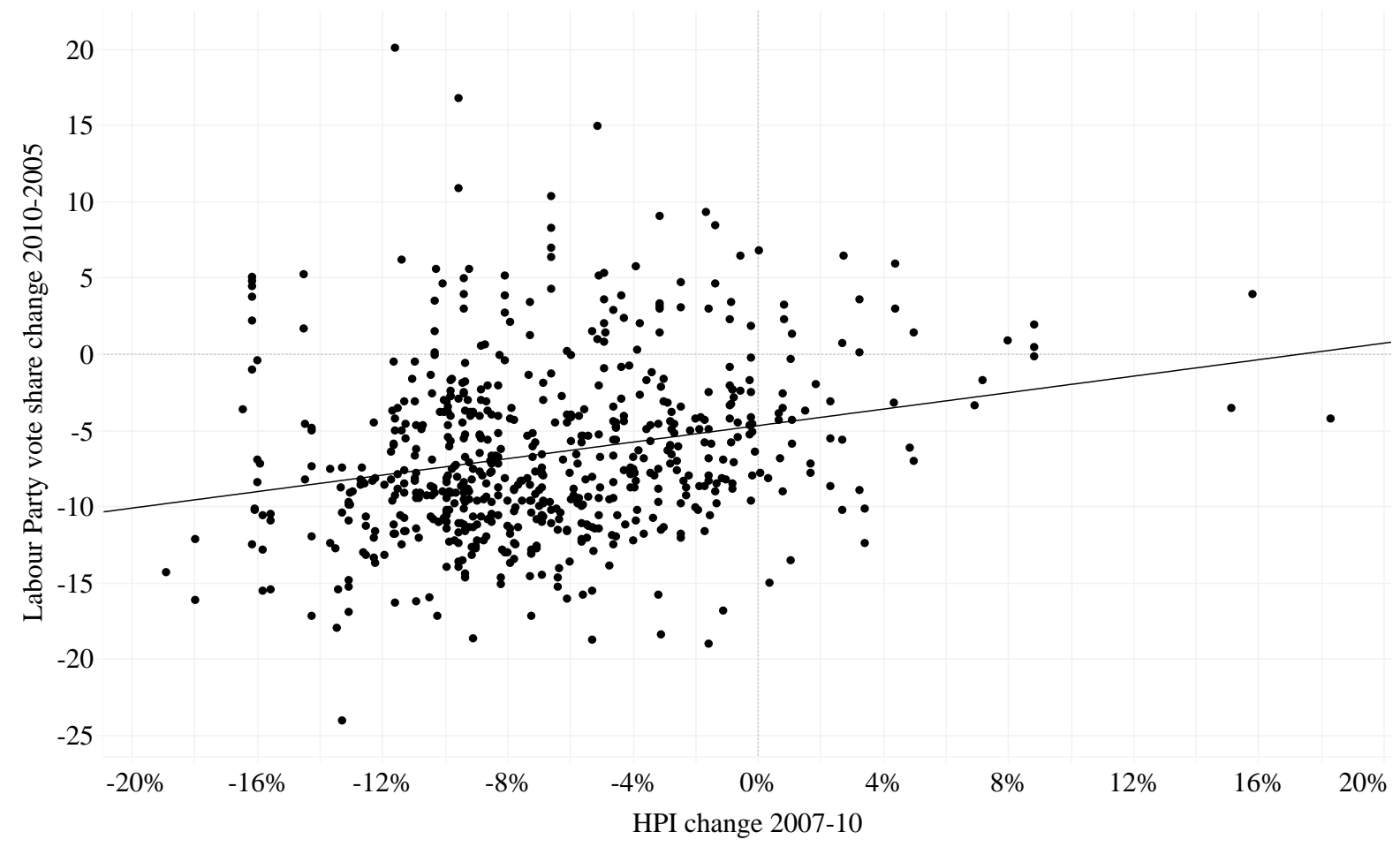

Source: Pippa Norris shared datasets, https://sites.hks.harvard.edu/fs/pnorris/Data/Data.htm; UK House Price Index, https://www.gov.uk/government/publications/about-the-uk-houseprice-index. The bivariate relationship is significant including $(.235 \mathrm{p}<.001)$ and excluding $(.237 \mathrm{p}<.001)$ potential outliers.

In combination with the other evidence we have discussed, it is reasonable to infer that a large segment of voters supported interventions in principle, but reacted negatively to policies they perceived as unfairly costly for themselves and disproportionately beneficial to the City and the wealthy generally. This outcome was striking for a government that strongly 
believed it had responded effectively to voter expectations about wealth and income protection by preventing a complete financial collapse.

\subsection{US policy responses and the political aftermath}

The US case over 2007-9 exhibits even more strongly the rising political pressure on governments to intervene during recent banking crises and the perils of doing so. The promarket Bush administration and the Federal Reserve were, like their British counterparts, opposed on ideological grounds to bailouts. Yet they moved fitfully but inexorably towards extensive interventions: the comparatively high level of institutional vetoes and political polarization produced extended legislative delays and outright failures in crucial areas. The most spectacular example was Congress's initial rejection of the Bush administration's Troubled Asset Relief Program (TARP) in September 2008. Yet for more than a year before this, the administration struggled to gain support in Congress for its proposals to tackle the deepening crisis.

The policy delays were exemplified by the indecision regarding the governmentsponsored enterprises (GSEs). Both the Fed and the government knew as early as March 2007 that taxpayer money would be required to rescue Fannie Mae and Freddie Mac, which then held or guaranteed about $\$ 5.2$ trillion of home mortgage debt and which were caught in the vortex of a collapsing securitized debt market (Bernanke, 2015, chap. 11; Frame et al., 2015; Wessel, 2009, chap. 10). But many in Congress feared a voter backlash from a bailout. Political consensus on action was unachievable before the GSEs faced collapse more than a year later, when Congress passed legislation on 30 July 2008 enabling public “conservatorship" and costly recapitalizations (Paulson, 2010: 139, 143).

Government indecision shifted the policy burden to the Fed, which had provided generalized liquidity support consistent with the Bagehot rule. From December 2007, the Fed 
began to depart substantially from this rule in offering a series of new liquidity facilities on increasingly generous terms; these grew dramatically after September 2008 (Bernanke, 2015: 410; Mishkin and White, 2016). By late October 2008, the Fed had also provided \$117 billion in direct support to Bear Stearns and AIG, testing the political limits of its authority and reinforcing the public perception that the authorities were bailing out Wall Street (Jacobe, 2008). For this reason, Barack Obama and John McCain, the Democratic and Republican candidates in the looming presidential elections, both felt compelled to oppose the GSE bailouts. There was no political appetite to repeat the favour for Lehman Brothers when it faced collapse in September (Paulson, 2010: 183). When its bankruptcy prompted a seizure of the interbank market, the Fed provided an $\$ 85$ billion direct loan to AIG in return for 79.9 percent of its stock, widely interpreted as providing a back-door bailout of major banks, including many foreign ones (CBS News, 2009; Pirrong, 2009). While a majority of voters in the pre-TARP period supported a Wall Street rescue, many worried that most costs would fall on taxpayers (Goldman, 2008; PewResearchCenter, 2008; Smith, 2014: 105).

When Treasury unveiled its sketchy TARP proposal to purchase illiquid assets from major banks it met bipartisan hostility in Congress. In an effort to build political support for the plan President Bush addressed voters, saying that while he understood why ordinary Americans disliked a bailout, "not passing a bill now would cost these Americans much more later" (New York Times, 2008). This plea was ineffective. Although retiring members of Congress were more supportive, others believed the weight of opinion in their constituencies opposed a bailout (McCarty et al., 2013: 214-223; Paulson, 2010: 286).

As in the British case, voter attitudes were complex and conflicted. The negative market reaction to Congress's rejection of TARP on 29 September threatened further wealth losses. A day after the vote, a Gallup/USA Today poll found 77 percent now supported government intervention via the same bill or a new plan (Gallup, 2008). Members of 
Congress reported calls from constituents concerned about their life savings (Geithner, 2015: 221; McCarty et al., 2013: 234-237; Morales, 2008). An Ipsos/McClatchy poll over October 2-6 found a clear majority of respondents supported a government "rescue" but not a "bailout" of financial markets, suggesting most voters favoured an intervention that did not let banks off the hook (Bowman and Rugg, 2010: 10). After Senate amendments including business tax breaks and an increase in deposit insurance to $\$ 250,000$ per account, Congress passed a revised bill on October 3. Yet 46 percent of Republicans voted against it. The Bush administration used the funds to buy preferred non-voting stock in banks, to inject a further $\$ 40$ billion into AIG (later increased to $\$ 70$ billion), to provide liability guarantees for Citigroup and Bank of America and assistance to the ailing automobile sector.

The passage of TARP (just) allowed the incumbent Republicans to avoid what the administration and senior leadership of both parties agreed would have been a policy catastrophe, but it underlined the knife-edge politics of modern bailouts. The administration and the Fed wanted to prevent a second Great Depression, but their political dilemma shared by Britain's Labour government - was that financialization meant this could not be done without a wholesale rescue of major financial firms, which voters clearly disliked (Bernanke, 2015: 145, 416; Bush, 2011: 458; Geithner, 2015: 248; Paulson, 2010). After the November 2008 elections, more Congressional Republicans distanced themselves from such interventions.

Housing market politics was also fraught. As in Britain, middle class American households have become increasingly leveraged since the early twentieth century, especially since the 1980s. References to the "sub-prime crisis" of 2007 notwithstanding, many middle income prime borrowers used mortgage debt to invest aggressively in property and these borrowers' share of total defaults increased sharply over 2006-9 (Albanesi et al., 2017; Adelino et al., 2017). By the 2000s, housing equity constituted the largest component of the 
middle class's net wealth, with pension assets second in importance (Kuhn et al., 2018; Wolff, 2017a: 568).

The housing market downturn was thus a crucial driver of middle class wealth losses after 2006. These losses were more evident to most voters by the November 2008 election than employment losses. Unemployment was then 6.8 percent - not yet unusually high for a recession and lower than in the 1908 election. Yet in a Pew survey in early 2009, 36 percent of respondents aged 30-49 believed their investment losses exceeded 20 percent; the figure for those aged 50-64 was 43 percent. Three-quarters of the latter group reported that the crisis had made it difficult for them to afford retirement (Morin and Taylor, 2009). Over 20072010, Fed household survey estimates show that median real household wealth fell precipitously by 44 percent to its lowest level since 1969, "[wiping] out 40 years of wealth gains" (Wolff, 2017b: 36). As middle class households had invested most during the housing boom, they suffered more in the bust. The average home ownership rate for the middle three wealth quintiles fell sharply from 78.2 to 67 percent, more than for other quintiles (Bricker et al., 2017: 1-2; Wolff, 2017b: 51).

The stock market collapse, given the rising dependence of middle-class Americans on DC retirement plans, compounded housing losses. Stock losses were even sharper than house price losses before the November 2008 election. The S\&P Composite stock index had fallen 42.6 percent from its pre-crisis peak to November 2008 , compared to a 15.5 percent fall for national house prices (Shiller, n.d.).

There is considerable evidence that wealth losses, concentrated among middle class households, significantly shaped voting behaviour. Antoniades and Calomiris show that the sharp contraction of mortgage credit was more important than rising unemployment in reducing voter support for incumbent Republicans before the election (Antoniades and Calomiris, 2018). Other studies and polls indicate that household exposure to stock market 
risk increased support for TARP and for Obama in the 2008 election among middle class and wealthier households (Hill et al., 2010; Meckler, 2008; Pagliari et al., 2018). Our own analysis also shows that at the county level, Republican losses in the November presidential election were significantly associated with house price losses (Figure 5).

Figure 5: House price index percentage change (2007-8), and Republican Party presidential vote percentage change (2004-8), all US counties.

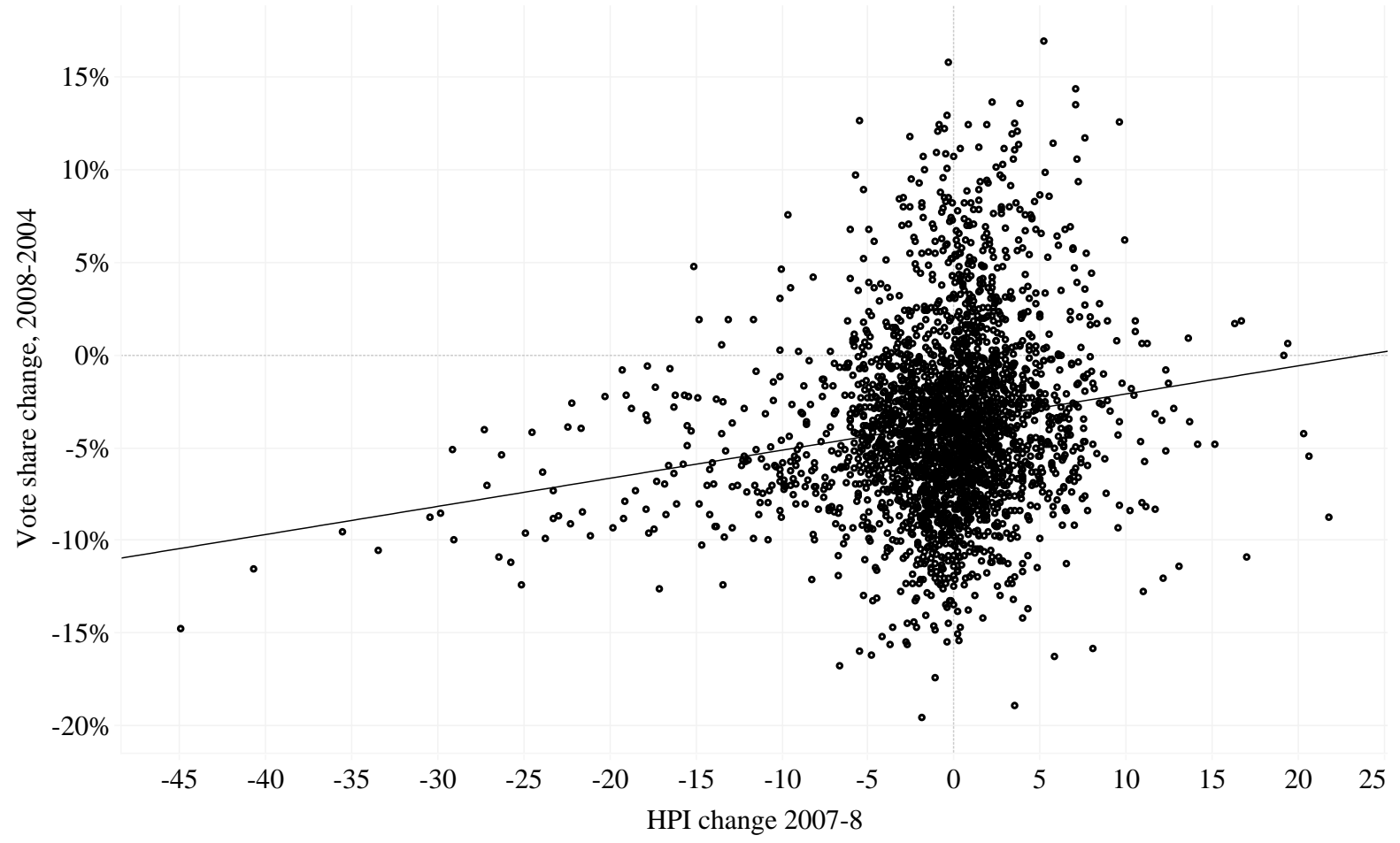

Source: (Bogin et al., 2016; MIT Election Data and Science Lab, 2018). The bivariate relationship is significant including $(.1643 \mathrm{p}<.001)$ and excluding $(.1646 \mathrm{p}<.001)$ potential outliers.

These losses were at odds with voters' great expectations and compounded their perceptions of the unfairness of the interventions. Polls immediately after TARP's passage indicated that most respondents believed Wall Street and elites would benefit most (Bowman and Rugg, 2010: 15-16). These perceptions were reinforced over time and layered onto long- 
running concerns among a majority of Americans of rising distributional unfairness, perceptions that aligned with rising measured wealth inequality (Bricker et al., 2017: 1-2; Wolff, 2017b: 10-12). BBC World Service polls found that a majority of American respondents agreed that "economic benefits and burdens have been unfairly shared in recent years" (52\% in 2008, 54\% in 2009, and 65\% in 2012) (BBC World Service, 2012). Similarly, a 2013 Pew survey found $47 \%$ of respondents agreeing that "inequality is a very big problem," 66\% agreeing that "the gap between rich and poor has increased" and $61 \%$ agreeing that "the system favours the wealthy" (PewResearchCenter, 2013: 21-22).

It was not difficult for the media and Democratic opponents to frame the Bush administration's interventions as ineffective and unfair (BBC Press Office, 2010; McCarty et al., 2013: 234-236). In the final month of the election campaign, Obama opened up a substantial lead over McCain, who had led briefly in most polls in early September but then lost ground as he failed to distance himself from the administration's policies (Jacobson, 2010: 216; RealClear Politics, 2008; Saad et al., 2008). Obama's election victory margin of 7.2 percent was substantial though not a landslide, perhaps because the government's policy interventions had prevented another Great Depression (Bartels, 2013: 53). The new administration would also suffer from the sustained economic trauma wrought by the crisis and its own policy interventions, contributing to large Democrat losses in the 2010 mid-term elections (Chwieroth and Walter 2019).

\section{The interwar period as a transitional era}

If our argument is correct, we would expect the combination of a post-1918 expansion of democracy and rising but still limited mass financialized wealth to have produced partial signs of this effect in the interwar period. We briefly illustrate the important US interwar case, which is consistent with this expectation. 
Although the level of financialization achieved in the United States by the late 1920s was substantially lower than that reached in recent decades, it was high by contemporary standards. A boom in mortgage financing in the 1920s and relatively high rates of owneroccupation (nearly half of all households) compared to Europe created a substantial constituency for protecting housing wealth among distressed urban homeowners and farmers, the construction industry and employees, banks, buildings and loan associations, mutual savings banks and insurance companies (Olson, 1988: 94). By 1933, a quarter or more of homeowners were in default (Federal Housing Finance Agency, 2011: 1). In July 1932, Congress passed the Federal Home Loan Bank Act to promote lending for house building and to reduce foreclosures, and the Emergency Relief and Construction Act to fund public works. Yet house prices continued to fall and bank failures accelerated in late 1932 before a final dramatic collapse in March 1933 (U.S. Federal Reserve, 1937: 909).

Policymakers had failed to tackle the underlying banking sector problems (Meltzer, 2010, chap. 5; Mishkin and White, 2016: 21). With the cooperation of Congressional Democrats, President Herbert Hoover established the Reconstruction Finance Corporation (RFC) with $\$ 500$ million of public funds in January 1932 to provide collateralized loans to local and state governments, banks and businesses. But a conservative lending policy limited its impact (Olson, 1988: 19-21). Meanwhile, Federal Reserve banks had pursued "liquidationist" policies in some regions and LOLR policies in others (Jalil, 2014; Richardson and Troost, 2009). The Fed's belief that enough had been done by early 1930 held despite accelerating bank failures, a position supported by the Hoover administration. Although the first Glass-Steagall act of February 1932 extended the Fed's ability to discount, its purchase program swung back towards caution by mid-year and worsened the crisis (Meltzer, 2010: 347, fn.83). 
The new President, Franklin Delano Roosevelt, shifted towards a bailout strategy. He immediately declared a national bank holiday and an accompanying emergency plan to protect depositors, reopen sound banks and reorganize others, and empower the Fed to lend more decisively (Burns, 1974: 46-47). The Emergency Banking Act (EBA) of March $9^{\text {th }}$ 1933 sanctioned the bank closures and gave the President powers to restructure and reopen closed banks. The RFC would take equity stakes in national and state banks (after government audits) to restore solvency and could provide collateralized loans to closed banks to unfreeze deposits (Olson, 1988: 64-65, 81). Recapitalizations enabled the gradual reopening of banks deemed solvent by the Treasury; insolvent banks were to be wound up. In a less financialized economy than today this was easier to achieve. The RFC often limited bank executives' salaries, helping to deflect criticism that it was enriching the wealthy (Olson, 1988: 126). The EBA also allowed the Fed to make advances in "exceptional and exigent circumstances" to member banks on any acceptable assets - a provision made permanent in the 1935 Banking Act.

The Roosevelt administration also moved quickly to support the wealth of ordinary households in a way that was absent in 1907-8. It adopted a de facto deposit insurance system by committing the Fed to lend money to Treasury-vetted banks, and it ultimately accepted a Congressional proposal for a formal deposit insurance regime managed by the Federal Deposit Insurance Corporation targeted at small savers (Silber, 2009: 20). It undertook new initiatives to promote home ownership and associated building via intervention in the distressed mortgage market (Fishback, 2017). The Home Owners' Loan Corporation (HOLC) was established as a government-sponsored corporation in June 1933 with RFC capital to borrow so as to refinance mortgages in default to prevent foreclosure and to buy bad loans from banks (Wheelock, 2008). The Federal Housing Administration (FHA) was also 
established in 1934 as a government agency to, among other things, insure and thereby subsidize mortgage lending.

Roosevelt won by a landslide in the November 1932 election with 57.4 percent of the popular vote compared to Hoover's 39.6 percent. We find, only after excluding a likely outlier and only in the presidential election, a weak negative relationship between state-level bank failures and the electoral swing against the incumbent Republican party in 1932 (Figure 6). ${ }^{4}$ However, the incumbent Republicans suffered significantly greater losses in 1932 than they did in 1908 in states in which bank failures were higher than average. ${ }^{5}$ This suggests that the political costs of financial instability were increasing for incumbents, though not yet at the level of 2008-10. Democratic dominance throughout the 1930s suggests that although the administration's efforts to protect ordinary householders' wealth were modest compared to the interventions of 2007-9, they were more consistent with most voters' expectations. Evidence from other interwar democracies paints a similar picture. ${ }^{6}$

\footnotetext{
${ }^{4}$ The bivariate relationship for House congressional seats is insignificant (-.0004, $\left.\mathrm{p}=.424\right)$, with no outliers detected.

${ }^{5}$ The difference in means for both seat losses ( 4.9 in 1932 versus 1.4 in $1908, \mathrm{t}=2.30, \mathrm{p}<.05$ ) and seat share swing (-42.7 percent in 1932 versus -5.2 percent in $1908, \mathrm{t}=2.76, \mathrm{p}<.05)$ is significant.

${ }^{6}$ See: Belgium and the Netherlands (Vanthemsche, 1991), Denmark (Hansen, 1994), Norway (Knutsen, 1994), and generally (James et al., 1991; Olsson, 1991).
} 
Figure 6: Bank failures by U.S. state, 1929 - 32, and percent change in Republican presidential candidate vote share, 1928-32.

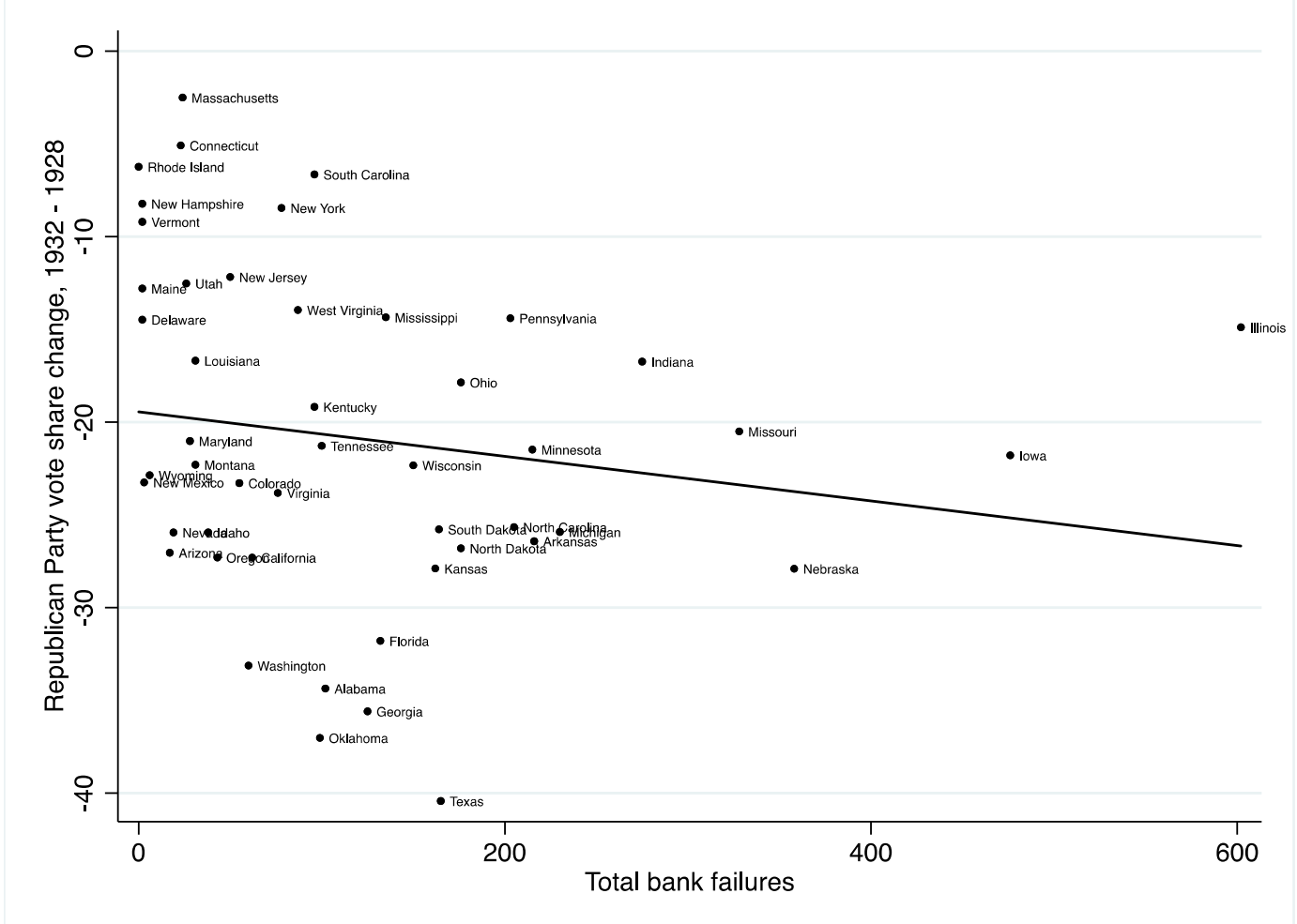

Source: (Moore, 1985; U.S. Federal Reserve, 1937). The bivariate relationship is insignificant including potential outliers $(-.1711, \mathrm{p}=.245)$. Excluding potential outliers, it is significant at $\mathrm{p}<.10(-.277, \mathrm{p}=.059)$.

\section{Conclusion}

Our panoramic analysis reveals the political impact of the rise of mass middle class wealth over two centuries. Rising democratization cannot account for the evolving form of mass politics we observe, as the case of the 1908 U.S. election suggests. ${ }^{7}$ In addition, the policy and political aftermath of the interwar US crisis is consistent with the rising but still

\footnotetext{
${ }^{7}$ Many African Americans, representing about 10 percent of the total population, were still disenfranchised but held little wealth. Women were enfranchised in 1920 and could own property.
} 
limited financialization of mass wealth at this time. It is the combination of financialized mass middle class wealth and electoral democracy that has transformed the aftermaths of systemic banking crises over the long run.

Democratic political institutions contribute in another way in an era of great expectations. In both cases after 2007, especially in the United States, institutional constraints in the context of political polarization generated substantial delays in government policy responses. These further undermined public perceptions of policy competence and exacerbated wealth losses, with powerful political consequences that were largely absent in the pre-1914 crises. This suggests that institutional and political features that constrain the ability of governments to undertake the efficient, effective and fair crisis interventions now expected by many voters make them more rather than less inclined to punish incumbents. The emergence of "asset dominance" and rising financial instability may thereby invert the rule that voters are more forgiving in circumstances of lower institutional clarity.

Might our findings be driven by evolving voter understandings of the appropriate role of the state in reducing risk to individuals? In the online appendix, using data from the World Values Survey (WVS) from 1981 to 2014, we show that public opinion over this period exhibits no discernable trend towards rising expectations of general government responsibilities. Our finding that voters increasingly expected extensive stabilizing financial interventions as private wealth accumulated over this period is thus probably specific to this policy domain.

Indeed, Ansell (2014) shows that rising housing wealth in democratic countries is associated with less support for general redistribution and social insurance policies. The long run expansion of the welfare state in both countries seems not to have substantially reduced rising mass anxiety about the threat crises pose to household wealth. If welfare transfers dampen societal discontent following crises (Anderson and Hecht, 2014), then voter anxiety 
about banking crises should be strongest in countries with weaker welfare states. Yet such anxieties were as evident in Britain, with its larger welfare state, as in the United States. Further research could assess whether more extensive welfare states in parts of Western Europe and Scandinavia provide a stronger buffer, although financialization and private "asset-based welfare" is increasingly evident even there, and such safety nets protect employment income more than household assets (Aalbers, 2016; Belfrage and Kallifatides, 2018).

Our argument has further implications. First, scholars should attend to how long term developments can transform household interests and social expectations regarding government policy responsibilities. Prospects for government survival in an era of rising mass wealth and financialization have become more fraught, in part because voters can have unrealistic expectations of government performance. Such expectations have also increased the political leverage of pro-bailout elites during crises - a kind of "political structural power" that accrues less from globalization than from financialization.

Second, although our findings are consistent with the claim that the rise of mass wealth can shift voters towards more conservative political views (Ansell, 2014), these effects may be dynamically unstable. Households may embrace the opportunities provided by financialization during asset booms, then demand government protection during busts. This likely exacerbates societal conflict and contributes to growing volatility in domestic and foreign policies.

Finally, the political aftermaths of modern crises may have become increasingly prolonged. The rising mass stake in asset markets can generate extended political economy cycles that disadvantage successive governments, as the political reversal experienced by the Democrats after November 2008 attests. The effects of crises and associated interventions also exacerbate the divergence in house prices between thriving and declining regions, 
reinforcing the perception of voters in the latter of being "left behind" and their willingness to reject neoliberal policy norms (Ansell, 2017b; Rodríguez-Pose, 2018). The rise of mass wealth and financialization may thus have contributed to the widespread erosion of faith in democratic politics and in longstanding foreign policies (Foa and Mounk, 2017). 


\section{$\underline{\text { References }}$}

Aalbers MB (2016) The Financialization of Housing: A Political Economy Approach.

London: Routledge.

Adelino M, Schoar A and Severino F (2017) Dynamics of Housing Debt in the Recent Boom and Great Recession. Working Paper 23502, October. National Bureau of Economic Research.

Albanesi S, Giorgi GD and Nosal J (2017) Credit Growth and the Financial Crisis: A New Narrative. Working Paper 23740, August. National Bureau of Economic Research. Anderson CJ and Hecht JD (2014) Crisis of Confidence?: The Dynamics of Economic Opinions during the Great Recession. In: Bermeo NG and Bartels LM (eds) Mass Politics in Tough Times: Opinions, Votes, and Protest in the Great Recession. New York, NY: Oxford University Press, pp. 40-71.

Andrews DM (1994) Capital Mobility and State Autonomy: Toward a Structural Theory of International Monetary Relations. International Studies Quarterly 38(2): 193-218. Ansell BW (2014) The Political Economy of Ownership: Housing Markets and the Welfare State. American Political Science Review 108(2): 383-402.

Ansell BW (2017a) Housing, Credit and Brexit. Available at:

http://users.ox.ac.uk/ polf0487/papers/Ansell\%20Brexit\%20Memo.pdf.

Ansell BW (2017b) Wealth Beyond Piketty. Paper prepared for Challenges to the

Contemporary World Order Workshop, Filzbach, Switzerland, 6-8 October.

Antoniades A and Calomiris CW (2018) Mortgage Market Credit Conditions and U.S.

Presidential Elections. Working Paper 24459, March. National Bureau of Economic Research.

Atkinson AB and Brandolini A (2013) Chapter 2. On the Identification of the Middle Class. In: Gornick JC and Jäntti M (eds) Income Inequality: Economic Disparities and the 
Middle Class in Affluent Countries. Stanford, CA: Stanford University Press, pp. 77100.

Atkinson AB, Hasell J, Morelli S, et al. (2017) The Chartbook of Economic Inequality - Data on Economic Inequality over the long-run. Institute for New Economic Thinking, Oxford Martin School. Available at:

https://www.chartbookofeconomicinequality.com/.

Bagehot W (1962) Lombard Street: A Description of the Money Market. Homewood, Ill.: R. D. Irwin.

Bartels LM (2013) Political Effects of the Great Recession. The ANNALS of the American Academy of Political and Social Science 650(1): 47-76.

Bartels LM (2014) Ideology and Retrospection in Electoral Responses to the Great Recession. In: Bartels LM and Bermeo N (eds) Mass Politics in Tough Times: Opinions, Votes and Protest in the Great Recession. Oxford, New York: Oxford University Press, pp. 185-224.

Bartels LM and Bermeo N (eds) (2014) Mass Politics in Tough Times: Opinions, Votes and Protest in the Great Recession. Oxford, New York: Oxford University Press.

BBC News (2007) Brown attacked over Northern Rock. 19 September. Available at: https://www.reuters.com/article/northernrock-brown-crisis/bank-crisis-deals-blow-tobrowns-reputation-idUKNOA92342420070919.

BBC Press Office (2010) Global poll: Governments misspend more than half our taxes. 9 September. Available at: http://www.bbc.co.uk/pressoffice/pressreleases/stories/2010/09_september/27/poll.sht $\mathrm{ml}$. 
BBC World Service (2012) Economic System Seen as Unfair: Global Poll. 25 April.

Available at: https://globescan.com/wp-

content/uploads/2012/03/BBC12_Economics.pdf.

Belfrage C and Kallifatides M (2018) Financialisation and the New Swedish Model.

Cambridge Journal of Economics 42(4): 875-900.

Bell S and Hindmoor A (2015) Taming the City? Ideas, Structural Power and the Evolution of British Banking Policy Amidst the Great Financial Meltdown. New Political Economy 20(3): 454-474.

Bernanke BS (2015) The Courage to Act: A Memoir of a Crisis and Its Aftermath. New York, NY: W. W. Norton.

Blyth M (2002) Great Transformations: The Rise and Decline of Embedded Liberalism. New York, NY: Cambridge University Press.

Blyth M and Matthijs M (2017) Black Swans, Lame Ducks, and the Mystery of IPE's Missing Macroeconomy. Review of International Political Economy 24(2): 203-231.

Board of Governors of the Federal Reserve System (2017) Report on the Economic WellBeing of U.S. Households in 2016. Washington, DC: Federal Reserve Board.

Bogin AN, Doerner WM and Larson WD (2016) Local House Price Dynamics: New Indices and Stylized Facts. FHFA Working Paper 16-01, 12 April. Washington, DC: FHFA.

Bowman K and Rugg A (2010) TARP, the Auto Bailout, and the Stimulus. AEI Studies in Public Opinion, 22 April. American Enterprise Institute.

Bricker J, Dettling LJ, Henriques A, et al. (2017) Changes in US Family Finances from 2013 to 2016: Evidence from the Survey of Consumer Finances. Federal Reserve Bulletin 103(3): $1-42$.

British Social Attitudes (n.d.) Key Findings. Available at: http://www.bsa.natcen.ac.uk/latestreport/british-social-attitudes-30/key-findings/trust-politics-and-institutions.aspx. 
Brock WR (1967) Lord Liverpool and Liberal Toryism 1820 to 1827. 3rd ed. London: Cass \& Co.

Brooks SM (2005) Interdependent and Domestic Foundations of Policy Change: The Diffusion of Pension Privatization Around the World. International Studies Quarterly 49(2): 273-294.

Bruner RF and Carr SD (2007) The Panic of 1907: Lessons Learned from the Market's Perfect Storm. Hoboken, NJ: John Wiley \& Sons.

Burns HM (1974) The American Banking Community and New Deal Banking Reforms, 19331935. Westport, CN: Greenwood Press.

Bush GW (2011) Decision Points. Reprint edition. New York, NY: Broadway Books. CBS News (2009) \$90B Of AIG’s Federal Rescue Went To Banks. 16 March. Available at: https://www.cbsnews.com/news/90b-of-aigs-federal-rescue-went-to-banks/.

Chwieroth JM and Walter A (2019) The Wealth Effect: How the Great Expectations of the Middle Class Have Changed the Politics of Banking Crises. Cambridge: Cambridge University Press.

Coates D (2009) Chickens Coming Home to Roost? New Labour at the Eleventh Hour. British Politics 4(4): 421-433.

Comptroller of the Currency (U.S.) (1909) Annual Report of the Comptroller of the Currency to the Second Session of the Sixty-First Congress of the United States. Washington, DC: U.S. Treasury.

Conant CA (1915) A History of Modern Banks of Issue. New York, NY: G.D. Putnam's Sons.

Corlett A and Judge L (2017) Home Affront: Housing Across the Generations. Wealth Series, Intergenerational Commission Report, September. Resolution Foundation. 
Crespo-Tenorio A, Jensen NM and Rosas G (2014) Political Liabilities: Surviving Banking Crises. Comparative Political Studies 47(7): 1047-1074.

Croft A (2007) Bank crisis deals blow to Brown's reputation. 19 September. Available at: https://www.reuters.com/article/northernrock-brown-crisis/bank-crisis-deals-blow-tobrowns-reputation-idUKNOA92342420070919.

Culpepper PD and Reinke R (2014) Structural Power and Bank Bailouts in the United Kingdom and the United States. Politics \& Society 42(4): 427-454.

Curtis KA, Jupille J and Leblang D (2014) Iceland on the Rocks: The Mass Political Economy of Sovereign Debt Resettlement. International Organization 68(3): 721740.

Darling A (2011) Back From the Brink. London: Atlantic Books.

Domanski D, Scatigna M and Zabai A (2016) Wealth inequality and monetary policy. BIS Quarterly Review March: 45-64.

Douglas PH and Director A (1931) The Problem of Unemployment. New York, NY: Macmillan.

Epstein GA (ed.) (2005a) Financialization and the World Economy. Cheltenham: Edward Elgar.

Epstein GA (2005b) Introduction: Financialization and the World Economy. In: Epstein GA (ed.) Financialization and the World Economy. Cheltenham: Edward Elgar, pp. 3-16. Federal Housing Finance Agency (2011) A Brief History of the Housing GovernmentSponsored Enterprises. Washington, DC: FFHA, Office of the Inspector General. Financial Services Authority (UK) $(2009,2012)$ Consumer Awareness of the FSA and Financial Regulation, Fieldwork Conducted by TNS Research International. London: Financial Services Authority. 
Financial Times (2009) Transcript: The full Gordon Brown interview. Financial Times, 31 August.

Finlayson A (2009) Financialisation, Financial Literacy and Asset-Based Welfare. The British Journal of Politics \& International Relations 11(3): 400-421.

Fioretos O (ed.) (2017) International Politics and Institutions in Time. Oxford: Oxford University Press.

Fishback PV (2017) How Successful Was the New Deal? The Microeconomic Impact of New Deal Spending and Lending Policies in the 1930s. Journal of Economic Literature 55(4): 1435-85.

Fisher DR (2009) The History of Parliament: The House of Commons 1820-1832, Vol. I: Introductory Survey, Appendices. Cambridge: Cambridge University Press. Fligstein N and Goldstein A (2015) The Emergence of a Finance Culture in American Households, 1989-2007. Socio-Economic Review 13(3): 575-601.

Foa RS and Mounk Y (2017) The Signs of Deconsolidation. Journal of Democracy 28(1): 515.

Foley M (2009) Gordon Brown and the Role of Compounded Crisis in the Pathology of Leadership Decline. British Politics 4(4): 498-513.

Frame WS, Fuster A, Tracy J, et al. (2015) The Rescue of Fannie Mae and Freddie Mac. Journal of Economic Perspectives 29(2): 25-52.

French S, Leyshon A and Wainwright T (2011) Financializing space, spacing financialization. Progress in Human Geography 35(6): 798-819.

Funke M, Schularick M and Trebesch C (2016) Going to Extremes: Politics After Financial Crises, 1870-2014. European Economic Review 88(C): 227-260.

Gallup (2008) Americans to Congress: Start From Scratch. 1 October. Available at: https://news.gallup.com/poll/110884/Americans-Congress-Start-From-Scratch.aspx. 
Gambles A (1999) Protection and Politics: Conservative Economic Discourse, 1815-1852.

Suffolk: Boydell Press.

Garrett G (1998) Partisan Politics in the Global Economy. Cambridge: Cambridge University Press.

Gayer AD, Rostow WW and Schwartz AJ (1975) The Growth and Fluctuation of the British Economy, 1790-1850: An Historical, Statistical, and Theoretical Study of Britain's Economic Development. Hassocks: Harvester Press.

Geithner TF (2015) Stress Test: Reflections on Financial Crises. New York, NY: Crown.

Gerring J and Cojocaru L (2015) Case-Selection: A Diversity of Methods and Criteria.

Unpublished paper. Available at:

https://pdfs.semanticscholar.org/7ff9/124c7427e6404cd6dbd27cbed8cef666b8f1.pdf.

Goldman D (2008) Americans Want Bailout, But Cost a Concern. CNN Money, 3 April.

Gorton G (1988) Banking Panics and Business Cycles. Oxford Economic Papers 40(4): 751781.

Grossman RS (2010) Unsettled Account: The Evolution of Banking in the Industrialized World since 1800. Princeton NJ: Princeton University Press.

Guiso L, Haliassos M, Jappelli T, et al. (2003) Household Stockholding in Europe: Where Do We Stand and Where Do We Go? Economic Policy 18(36): 125-170.

Hacker JS and Pierson P (2010) Winner-Take-All Politics: How Washington Made the Rich Richer, and Turned Its Back on the Middle Class. New York, NY: Simon \& Schuster. Haldane AG (2016) Whose Recovery? Speech given by Andrew G Haldane, Chief Economist, Bank of England, 30 June. Bank of England.

Haldane AG (2018) How Monetary Policy Affects Your GDP, 2018 Finch Lecture, University of Melbourne. London: Bank of England. 
Haldane AG and May RM (2011) Systemic Risk in Banking Ecosystems. Nature 469 (7330): $351-355$.

Hansen PH (1994) Production Versus Currency: The Danish Central Bank in the 1920s. In:

Teichova A, Gourvish TR, and Pogány Á (eds) Universal Banking in Twentieth Century Europe: Finance, Industry and State in North and Central Europe. Aldershot and Brookfield, VT: Edward Elgar, pp. 59-78.

Hellwig T and Samuels D (2007) Voting in Open Economies: The Electoral Consequences of Globalization. Comparative Political Studies 40(3): 283-306.

Hill SJ, Herron MC and Lewis JB (2010) Economic Crisis, Iraq, and Race: A Study of the 2008 Presidential Election. Election Law Journal: Rules, Politics, and Policy 9(1): $41-62$.

Hoffman PT, Postel-Vinay G and Rosenthal J-L (2009) Surviving Large Losses: Financial Crises, the Middle Class, and the Development of Capital Markets. Cambridge, MA: Harvard University Press.

Hopkin J and Viarengo M (2012) Inequality, Poverty and the 2010 Election. In: Baldini G and Hopkin J (eds) Coalition Britain: The UK Election of 2010. Manchester: Manchester University Press, pp. 111-130.

House of Commons Library, United Kingdom (2013) The History of the Parliamentary Franchise, Research Paper 13/14.

International Monetary Fund (2010) Fiscal Monitor: Navigating the Fiscal Challenges Ahead. Washington, DC: International Monetary Fund. Jacobe D (2008) Six in 10 Oppose Wall Street Bailouts. 3 April. Available at: http://news.gallup.com/poll/106114/Six-Oppose-Wall-Street-Bailouts.aspx Jacobson GC (2010) George W. Bush, the Iraq War, and the Election of Barack Obama. Presidential Studies Quarterly 40(2): 207-224. 
Jaevicius A, Huston S and Baum A (2015) Two Centuries of Farmland Prices in England. Available at: http://ssrn.com/abstract=2604130.

Jalil AJ (2014) Monetary Intervention Really Did Mitigate Banking Panics During the Great Depression: Evidence Along the Atlanta Federal Reserve District Border. The Journal of Economic History 74(1): 259-273.

James H, Lindgren H and Teichova A (1991) The Role of Banks in the Interwar Economy. Cambridge and Paris: Cambridge University Press; Éditions de la Maison des sciences de l'homme.

Jaremski M and Rousseau PL (2018) The Dawn of an 'Age of Deposits' in the United States. Journal of Banking \& Finance 87 (Supplement C): 264-281.

Johnson L and Williamson SH (2017) What Was the U.S. GDP Then? Measuring Worth. Available at: https://measuringworth.com/usgdp12/.

Johnson S and Kwak J (2010) 13 Bankers: The Wall Street Takeover and the Next Financial Meltdown. New York, NY: Pantheon Books.

Jordà Ò, Schularick M and Taylor AM (2016) The Great Mortgaging: Housing Finance, Crises and Business Cycles. Economic Policy (85): 107-140.

Kahneman D and Tversky A (1984) Choices, Values, and Frames. American Psychologist 39(4): 341-350.

Kindleberger CP and Aliber RZ (2011) Manias, Panics and Crashes: A History of Financial Crises. Basingstoke and New York, NY: Palgrave Macmillan.

Knoll K, Schularick M and Steger T (2017) No Price Like Home: Global House Prices, 18702012. American Economic Review 107(2): 331-53.

Knutsen S (1994) Norwegian Banks and the Legacy of the Interwar Years. In: Gourvish TR, Pogány Á, and Teichova A (eds) Universal Banking in the Twentieth Century: 
Finance, Industry and State in North and Central Europe. Aldershot: Edward Elgar, pp. 77-95.

Kuhn M, Schularick M and Steins U (2018) Income and Wealth Inequality in America, 19492016. CEPR, London. Available at: http://www.wiwi.unibonn.de/kuhn/paper/Wealthinequality_7June2018_edt.pdf.

Laeven L and Valencia F (2013) Systemic Banking Crises Database. IMF Economic Review 61(2): 225-270.

Langley P (2009) The Everyday Life of Global Finance: Saving and Borrowing in AngloAmerica. Oxford and New York, NY: Oxford University Press.

Lieberman ES (2005) Nested Analysis as a Mixed-Method Strategy for Comparative Research. American Political Science Review 99(3): 435-452.

Lindert PH (1986) Unequal English Wealth Since 1670. Journal of Political Economy 94(6): $1127-1162$.

MacIntyre AJ (2003) The Power of Institutions: Political Architecture and Governance. Cornell studies in political economy. Ithaca, NY: Cornell University Press. McCarty N, Poole KT and Rosenthal H (2013) Political Bubbles: Financial Crises and the Failure of American Democracy. Princeton, NJ: Princeton University Press.

McCarty N, Poole K and Rosenthal H (2015) Polarized America: The Dance of Ideology and Unequal Riches. 2nd ed. Cambridge, MA: MIT Press.

McCulley RT (1992) Banks and Politics During the Progressive Era: The Origins of the Federal Reserve System, 1897-1913. New York, NY and London: Garland.

Meckler L (2008) Campaign '08: Independent Voters Move Toward Obama; New Poll Indicates That Democrat Ticket Is Benefiting From Financial Crisis. Wall Street Journal, 7 October. New York. 
Meltzer AH (2010) A History of the Federal Reserve, Volume 1: 1913-1951. Chicago:

University of Chicago Press.

Mian A, Sufi A and Trebbi F (2014) Resolving Debt Overhang: Political Constraints in the Aftermath of Financial Crises. American Economic Journal: Macroeconomics 6(2): $1-28$.

Mishkin FS and White EN (2016) Unprecedented Actions: The Federal Reserve's Response to the Global Financial Crisis in Historical Perspective. In: Bordo MD and Wynne MA (eds) The Federal Reserve's Role in the Global Economy: A Historical Perspective. New York, NY: Cambridge University Press, pp. 220-258.

MIT Election Data and Science Lab (2018) County Presidential Election Returns 2000-2016. Available at: https://dataverse.harvard.edu/dataset.xhtml?persistentId=doi:10.7910/DVN/VOQCH Q.

Moen J and Tallman EW (1992) The Bank Panic of 1907: The Role of Trust Companies. The Journal of Economic History 52(3): 611-630.

Moore JL (1985) Congressional Quarterly's Guide to U.S. Elections, Second Edition. 2nd ed. Washington, DC: Congressional Quarterly, Inc.

Morales L (2008) Initial Bailout Falling Out of Favor With Americans. 9 December. Available at: http://news.gallup.com/poll/113047/Americans-Falling-Favor-InitialBailout.aspx.

Morin R and Taylor P (2009) Different Age Groups, Different Recessions. In: Pew Research Center's Social \& Demographic Trends Project. Available at: http://www.pewsocialtrends.org/2009/05/14/different-age-groups-differentrecessions/. 
Munck GL and Snyder R (2007) Debating the Direction of Comparative Politics: An Analysis of Leading Journals. Comparative Political Studies 40(1): 5-31.

New York Times (2008) President Bush's Speech to the Nation on the Economic Crisis. The New York Times, 24 September. Available at: https://www.nytimes.com/2008/09/24/business/economy/24text-bush.html Oatley T (2004) Why is Stabilization Sometimes Delayed? Reevaluating the Regime-Type Hypothesis. Comparative Political Studies 37(3): 286-312.

Offer A (1991) Farm Tenure and Land Values in England, c. 1750-1950. The Economic History Review 44(1): 1-20.

Office for National Statistics (2013) A Century of Home Ownership and Renting in England and Wales. Available at: http://webarchive.nationalarchives.gov.uk/20160105160709/http://www.ons.gov.uk/o ns/rel/census/2011-census-analysis/a-century-of-home-ownership-and-renting-inengland-and-wales/short-story-on-housing.html.

Office for National Statistics (2014) Pension Trends: Compendium. ONS. Available at: https://www.ons.gov.uk/economy/investmentspensionsandtrusts/compendium/pension trends/2014-11-28.

Office for National Statistics (2017) Household Disposable Income and Inequality in the UK. ONS. Available at: https://www.ons.gov.uk/peoplepopulationandcommunity/personalandhouseholdfinanc es/incomeandwealth/bulletins/householddisposableincomeandinequality/financialyear ending2016.

Olson JS (1988) Saving Capitalism: The Reconstruction Finance Corporation and the New Deal, 1933-1940. Princeton, NJ: Princeton University Press. 
Olsson U (1991) Comparing the Interwar Banking History of Five Small Countries in Northwest Europe. In: James $\mathrm{H}$, Lindgren $\mathrm{H}$, and Teichova A (eds) The Role of Banks in the Interwar Economy. Cambridge: Cambridge University Press, pp. 26-34.

Orbell J and Turton A (2001) British Banking: A Guide to Historical Records. Studies in British business archives. Aldershot: Ashgate.

Pagliari S, Phillips L and Young KL (2018) The Financialization of Policy Preferences: Financial Asset Ownership, Regulation and Crisis Management. Socio-Economic Review forthcoming.

Paulson HM (2010) On the Brink: Inside the Race to Stop the Collapse of the Global Financial System. New York, NY: Business Plus.

PewResearchCenter (2008) Obama Seen As Better Able to Address Crisis; 57\% of Public Favors Wall Street Bailout. 23 September. Washington, DC. Available at: http://assets.pewresearch.org/wp-content/uploads/sites/5/legacy-pdf/452.pdf.

PewResearchCenter (2013) Economies of Emerging Markets Better Rated During Difficult Times. Available at: http://www.pewglobal.org/2013/05/23/chapter-3-inequality-andeconomic-mobility/.

Piketty T and Zucman G (2014) Capital is Back: Wealth-Income Ratios in Rich Countries 1700-2010. The Quarterly Journal of Economics 129(3): 1255-1310.

Piketty T and Zucman G (2015) Wealth and Inheritance in the Long Run. In: Bourguignon ABA and F (ed.) Handbook of Income Distribution. Handbook of Income Distribution. Elsevier, pp. 1303-1368.

Pirrong C (2009) AIG Bailout: A Goldman Rescue in Drag? 22 November. Available at: https://seekingalpha.com/article/174686-aig-bailout-a-goldman-rescue-in-drag. 
Powell GB and Whitten GD (1993) A Cross-National Analysis of Economic Voting: Taking Account of the Political Context. American Journal of Political Science 37(2): 391414.

Pressnell LS (1956) Country Banking in the Industrial Revolution. Oxford: Clarendon Press. Quaglia L (2009) The 'British Plan' as a Pace-Setter: The Europeanization of Banking Rescue Plans in the EU? JCMS: Journal of Common Market Studies 47(5): 10631083.

RealClear Politics (2008) General Election 2008 - McCain vs. Obama. Available at: /epolls/2008/president/us/general_election_mccain_vs_obama-225.html.

Reinhart CM (2010) This Time is Different Chartbook: Country Histories on Debt, Default, and Financial Crises. Working Paper 15815, March. National Bureau of Economic Research.

Reinhart CM and Rogoff KS (2009) This Time Is Different: Eight Centuries of Financial Folly. Princeton, NJ: Princeton University Press.

Richardson G and Troost W (2009) Monetary Intervention Mitigated Banking Panics during the Great Depression: Quasi-Experimental Evidence from a Federal Reserve District Border, 1929-1933. Journal of Political Economy 117(6): 1031-1073.

Rodríguez-Pose A (2018) The Revenge of the Places That Don't Matter (And What to Do About It). Cambridge Journal of Regions, Economy and Society 11(1): 189-209. Roe A (1971) The Financial Interdependence of the Economy. London: Chapman and Hall. Rohlfing I (2008) What You See and What You Get: Pitfalls and Principles of Nested Analysis in Comparative Research. Comparative Political Studies 41(11): 14921514.

Rosas G (2006) Bagehot or Bailout? An Analysis of Government Responses to Banking Crises. American Journal of Political Science 50(1): 175-191. 
Rosas G (2009) Curbing Bailouts: Bank Crises and Democratic Accountability in

Comparative Perspective. Ann Arbor, MI: University of Michigan Press.

Saad L, Jones JM and Newport F (2008) Obama's Road to the White House: A Gallup

Review. Available at: http://news.gallup.com/poll/111742/Obamas-Road-White-

House-Gallup-Review.aspx.

Sanders E (1999) Roots of Reform: Farmers, Workers, and the American State 1877 - 1917.

Chicago: University of Chicago Press.

Schwartz HM and Seabrooke L (2009) The Politics of Housing Booms and Busts.

International political economy series. Basingstoke: Palgrave Macmillan.

Shiller RJ (n.d.) Online Data - Robert Shiller. Available at:

http://www.econ.yale.edu/ shiller/data.htm.

Short J (2002) Economic History of Retirement in the United States. Available at:

https://eh.net/encyclopedia/economic-history-of-retirement-in-the-united-states/.

Silber WL (2009) Why Did FDR's Bank Holiday Succeed? FRBNY Economic Policy Review 15(1): 19-30.

Smith MG (2014) Three Essays on the Political Economy of Corporate Bailouts.

Unpublished $\mathrm{PhD}$ dissertation, Columbia University.

Taus ER (1943) Central Banking Functions of the United States Treasury, 1789-1941. New

York, NY: Columbia University Press.

Thomas R and Dimsdale NH (2017) A Millennium of UK Data: Bank of England OBRA

dataset. Bank of England. Available at:

http://www.bankofengland.co.uk/research/Pages/onebank/threecenturies.aspx.

Thomas SE (1934) The Rise and Growth of Joint Stock Banking. London: Pitman.

Tooze A (2018) Crashed: How a Decade of Financial Crises Changed the World. New York:

Viking. 
Tsebelis G (2002) Veto Players: How Political Institutions Work. Princeton, NJ: Princeton University Press.

Turner JD (2014) Banking in Crisis: The Rise and Fall of British Banking Stability, 1800 to the Present. Cambridge: Cambridge University Press.

United Nations Human Settlements Program (2006) United Nations Human Settlements Programme 2005 Annual Report. United Nations.

U.S. Department of Commerce and Labor (1910) Statistical Abstract of the United States: 1909. Washington: Government Printing Office.

U.S. Federal Reserve (1937) Bank Suspensions, 1921-1936. Federal Reserve Bulletin September: 866-910.

van der Cruijsen C, de Haan J, Jansen D-J, et al. (2013) Knowledge and Opinions About Banking Supervision: Evidence From a Survey of Dutch Households. Journal of Financial Stability 9(2): 219-229.

van der Zwan N (2014) Making sense of financialization. Socio-Economic Review 12(1): 99129.

Vanthemsche G (1991) States, Banks, and Industry in Belgium and the Netherlands, 1919 1939. In: James H, Lindgren H, and Teichova A (eds) The Role of Banks in the Interwar Economy. Cambridge: Cambridge University Press, pp. 104-121.

Watson M (2007) The Political Economy of International Capital Mobility. International political economy series. Basingstoke: Palgrave Macmillan.

Wessel D (2009) In FED We Trust: Ben Bernanke's War on the Great Panic. Reprint edition. New York, NY: Crown Business.

Wheelock DC (2008) The Federal Response to Home Mortgage Distress: Lessons from the Great Depression. Federal Reserve Bank of St. Louis Review 90(3): 133-148. 
Wolff EN (2017a) A Century of Wealth in America. Cambridge, MA: Belknap Press of Harvard University Press.

Wolff EN (2017b) Household Wealth Trends in the United States, 1962 to 2016: Has Middle Class Wealth Recovered? Working Paper 24085, November. National Bureau of Economic Research.

Woll C (2014) The Power of Inaction: Bank Bailouts in Comparison. Cornell Studies in Political Economy. Ithaca, NY: Cornell University Press.

World Wealth \& Income Database (2017) WID - World Wealth \& Income Database. Available at: http://wid.world/. 